\title{
Growth performance, tolerance and vigor dynamics of Salvia candidissima subsp. occidentalis Hedge against heavy metal contamination
}

\author{
Gulcin Isik (D) $1{ }^{*}$
}

${ }^{1}$ University, Department of Biology, Faculty of Science, Eskisehir Technical University, Eskişehir, Turkey

\begin{abstract}
In this study, ecotoxicological and ecophysiological effects of some different heavy metal compounds $\left(\mathrm{CdCl}_{2}, \mathrm{PbCl}_{2}\right.$, and $\left.\mathrm{CuCl}_{2}\right)$ on Salvia candidissima subsp. occidentalis Hedge (Lamiaceae) were examined. Seeds of this plant were exposed to three different concentrations of $\mathrm{CdCl}_{2}(2,6,10$ ppm), $\mathrm{PbCl}_{2}(50,100,500 \mathrm{ppm})$, and $\mathrm{CuCl}_{2}(20,60,150 \mathrm{ppm})$. The results indicated that increasing $\mathrm{CdCl}_{2}$ and $\mathrm{PbCl}_{2}$ concentrations had no specific inhibitory impacts on seed germination rates, growth performance, biomass, and seedling vigor index, but increasing concentrations of $\mathrm{CuCl}_{2}$ had significant inhibitory effects on these parameters. The metal tolerance index of all applications showed that all heavy metal treatments reduce this value.
\end{abstract}

\section{ARTICLE HISTORY}

Received: Apr. 12, 2021

Revised: June 03, 2021

Accepted: June 09, 2021

\section{KEYWORDS}

Ecophysiology

Heavy metal

Salvia

Vigor

Tolerance

\section{INTRODUCTION}

Genus Salvia L. has 100 different species in Turkey, Salvia candidissima Vahl is a species which belongs to Group D and has two subspecies (Davis, 1985; Sen-Utsukarci et al., 2019). Salvia candidissima subsp. occidentalis Hedge is one of these subspecies. It differs from the other subspecies with smaller leaves, thick indumentum and white flowers (Figure $1 \mathrm{a}, \mathrm{b}$ ). This taxon is widespread and common for Inner Anatolia, Turkey (Davis, 1985).

Genus Salvia has rich chemical compounds like the other members of its family. Salvia species is important as medicinal plants. There are some pharmacological studies about $S$. candidissima (Ulubelen and Topcu, 1998), but not any other studies about its ecological or ecophysiological characteristics. From the aboveground parts of $S$. candidissima, 3oxosalvipisone, was acquired with 11ß-hydroxymanoyl oxide, 8,13-diepimanoyl oxide, spathulenol, salvigenin, crysoeriol, diosmetin and $o, p$-dimethoxybenzoic acid (Ulubelen et al., 1995). From the roots of $S$. candidissima subsp. candidissima, new diterpenes, new steroidal ester and $\alpha$-amyrin acetate were insulated (Ulubelen et al., 1997). In addition to diterpenoids, 11-hydroxy-12-methoxyabieta-8,11,13-trien and 1-oxosalvipisone, 14-oxopimaric acid, ferruginol, horminone, 7-acetylhorminone, cryptanol, montbretyl 12-methyl ether,

\footnotetext{
*CONTACT: Gulcin Isik $\bigotimes$ glcnylmz@gmail.com Technical University, Eskişehir, Turkey 
microstegiol, 1-oxoaethiopinone and salvipisone were obtained (Ulubelen et al., 1992a), a new diterpene, candidissiol was insulated from the underground parts of $S$. candidissima (Ulubelen et al., 1992b).

In consequence of increasing industrial human actions, releasing heavy metals to the nature (water, air and soil) has become a scientific matter. All components of the ecosystem are affected of heavy metal contamination in different levels. Heavy metal contamination of agricultural areas is a worldwide issue (Angelova et al., 2017). Heavy metals are not degradable by biological pathways and permanent in the ecological environment continually (Singh \& Prasad, 2011). Heavy metals can join the food chain after they are taken from the soil by plants. A deep understanding of metal uptake, transport, and defense processes in plants is required to improve metal uptake under metal-limiting conditions to increase vegetative productivity. (Gangwar et al., 2014).

For plant species, cadmium is not an essential but a toxic element that can be actively extracted from the soil, high concentrations of cadmium can have adverse effects on the production and standard of the crop, as well as harm humans via the food chain (He et al., 2008). Lead is an inherently consisting heavy metal element and main human origin basis of $\mathrm{Pb}$ contains metal mining activities, gem-dressing, and molding; pile fabrication; removal of lead containing outcomes without control processes, such as used up piles and computer products, etc. (Scheuhammer et al., 2008). Copper element is an essential micronutrient for the life of plants, but it is thought to have a toxic effect by causing abiotic stress at high concentrations (Gill et al., 2012).

The aims of this study were to observe the reactions of $S$. candidissima subsp. occidentalis (Fig 1) against pollution factors such as different heavy metal concentrations, like germination characteristics, shoot and root growth and production as biomass, seedling growth, seedling vigor index and metal tolerance index.

Figure 1. a. Flower and, b. Seeds of Salvia candidissima subsp. Occidentalis.
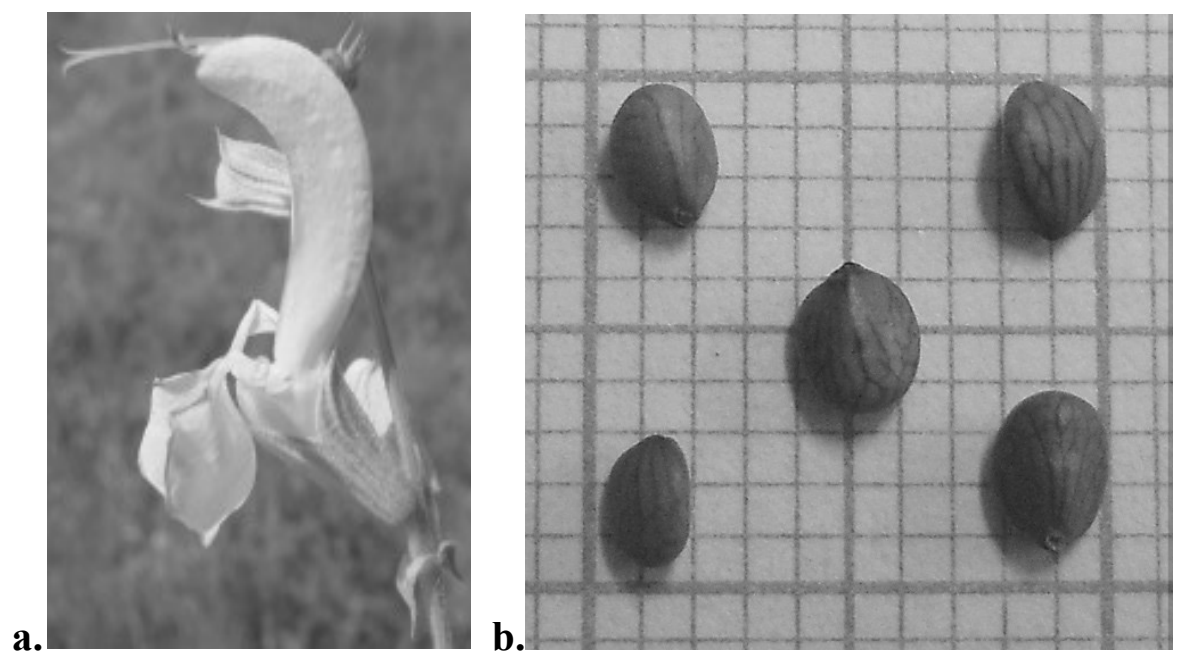

\section{MATERIAL and METHODS}

The plant samples were collected from study area (Borabey Pond environs, Eskisehir Technical University) which is located at Eskisehir, Turkey. S. candidissima subsp. occidentalis seeds were used in this study. The seed germination experiments were performed out in MLR-350 Model Sanyo (Japan) plant growth chamber. During germination experiments, a photoperiod with 8 hours light $/ 16$ hours dark and stable temperature $\left(+25^{\circ} \mathrm{C}\right)$ were applied (Yucel, 2000). Based on literature data and hazard levels, different concentrations of $\mathrm{CdCl}_{2}(2,6,10 \mathrm{ppm})$, $\mathrm{PbCl}_{2}(50,100,500 \mathrm{ppm})$ and $\mathrm{CuCl}_{2}(20,60,150 \mathrm{ppm})$ were applied. Germination experiments 
were carried out in petri dishes ( $9 \mathrm{~cm}$ diameter) with two layers of circular filter papers and 25 seeds were sowed at each petri dish. Seed beds were filled with $9 \mathrm{ml}$ of solutions including different heavy metal concentrations. Control groups were prepared with distilled water. The seed sowed beds kept into plant growth cabinet for 10 days. In order to accept the seed as germinated, the root tip must contact the germination bed (Yucel \& Yilmaz, 2009). In the course of the experiments, controls were made every day at a specific time. End of the tenth day, hypocotyl and radicle lengths were measured by using rulers, then hypocotyls and radicles were separated to weigh each of them. For observing wet amounts of hypocotyl and radicle, fresh shoots and roots were measured directly without any application by ruler and for dry amounts of hypocotyl and radicle, shoots and roots were dried at $105^{\circ} \mathrm{C}$, for 48 hours at sterilizer. Seedling vigor index (SVI) was calculated with respect to Murthy and Tejavathi (2016). Metal tolerance index (MTI) is calculated according to Turner and Marshall (1972).

The data obtained from experiments were tested statistically with the SPSS Statistics 20 package program, One-Way ANOVA Test with a p-value less than 0.05 considered statistically significant.

\section{RESULTS}

Seed germination experiments showed that increasing $\mathrm{PbCl}_{2}$ and $\mathrm{CdCl}_{2}$ concentrations has no significant effect on seed germination percentage $(F=0.681 ; d f=9.20 ; p>0.05)$, seedling growth (For hypocotyl $F=10.079 ; d f=9.20 ; p>0.05$, for radicle $F=11.558 ; d f=9.20 ; p>0.05$ ), biomass (For hypocotyl $F=1.452 ; d f=9.20 ; p>0.05$, for radicle $F=1.824 ; d f=9.20 ; p>0.05$ ) and SVI $(F$ $=1.815 ; d f=9.20 ; p>0.05)$ value of $S$. candidissima subsp. occidentalis, but increasing $\mathrm{CuCl}_{2}$ concentrations had an inhibitory effect of all ecophysiological parameters of $S$. candidissima subsp. occidentalis (Table 1).

Table 1. Ecophysiological parameters observed after different heavy metal applications.

\begin{tabular}{ccccccccc}
\hline \multicolumn{1}{c}{ Application } & $\begin{array}{c}\% \\
\text { Germination }\end{array}$ & $\begin{array}{c}\text { Hypocotyl } \\
\text { length }(\mathrm{cm})\end{array}$ & $\begin{array}{c}\text { Radicle } \\
\text { length }\end{array}$ & $\begin{array}{c}\text { Hypocotyl } \\
\text { biomass (mg) }\end{array}$ & $\begin{array}{c}\text { Radicle } \\
\text { biomass }\end{array}$ & SVI & MTI \\
\hline \multicolumn{2}{c}{ Control } & 31 & 2.52 & 5.35 & 7.50 & 2.27 & 83.48 & 1.000 \\
\hline $\mathrm{CdCl}_{2}$ & $2 \mathrm{ppm}$ & 39 & 2.80 & 4.99 & 5.77 & 2.63 & 113.67 & 0.708 \\
\cline { 2 - 10 } & $6 \mathrm{ppm}$ & 35 & 2.04 & 2.74 & 5.93 & 1.90 & 73.81 & 0.523 \\
\cline { 2 - 10 } & $10 \mathrm{ppm}$ & 44 & 2.84 & 3.70 & 12.13 & 4.03 & 126.19 & 0.586 \\
\hline $\mathrm{PbCl}_{2}$ & $50 \mathrm{ppm}$ & 36 & 2.41 & 5.15 & 5.53 & 2.50 & 92.72 & 0.814 \\
\cline { 2 - 10 } & $100 \mathrm{ppm}$ & 44 & 2.25 & 4.10 & 9.50 & 2.90 & 104.46 & 0.760 \\
\cline { 2 - 10 } & $500 \mathrm{ppm}$ & 39 & 2.35 & 2.71 & 8.27 & 2.23 & 93.47 & 0.518 \\
\hline $\mathrm{CuCl}_{2}$ & $20 \mathrm{ppm}$ & 44 & 2.12 & 1.49 & 11.57 & 2.97 & 93.62 & 0.233 \\
\cline { 2 - 9 } & $60 \mathrm{ppm}$ & 24 & 1.73 & 1.14 & 6.03 & 0.93 & 42.53 & 0.170 \\
\cline { 2 - 9 } & $150 \mathrm{ppm}$ & 24 & 1.02 & 0.60 & 5.77 & 0.87 & 26.70 & 0.097 \\
\hline
\end{tabular}

Biomass data observed from this research showed that increasing $\mathrm{PbCl}_{2}$ and $\mathrm{CdCl}_{2}$ concentrations had no significant effect on biomass of $S$. candidissima subsp. occidentalis, but increasing $\mathrm{CuCl}_{2}$ concentrations had an inhibitory effect on biomass of $S$. candidissima subsp. occidentalis (Table 1).

Results about root and stem growth of seedlings showed that increasing $\mathrm{CdCl}_{2}$ concentrations had no significant effect on root and stem growth of seedlings of $S$. candidissima subsp. occidentalis, but increasing $\mathrm{PbCl}_{2}$ and $\mathrm{CuCl}_{2}$ concentrations had an inhibitory effect on root and stem growth of seedlings of $S$. candidissima subsp. occidentalis (Table 1). 
MTI values of all heavy metal applications showed that all treatments decreased metal tolerance index value $(F=48.845 ; d f=9.30 ; p<0.05)$. MTI parameter is more critical than other ecophysiological data. The sensitivity of experiments can be examined through the metal tolerance index.

\section{DISCUSSION}

In this study, an examination of the ecophysiological effects of various concentrations of heavy metals which are $\mathrm{CdCl}_{2}(2,6,10 \mathrm{ppm}), \mathrm{CuCl}_{2}(20,60,150 \mathrm{ppm})$ and $\mathrm{PbCl}_{2}(50,100,500$ $\mathrm{ppm}$ ) on $S$. candidissima subsp. occidentalis were investigated. Determining the "seed germination behavior" is essential to protect the natural habitats and gene pools of plant species, and supplying the incrasing request for plant-based outcomes can only be probable by conserving and growing natural plants (Yucel \& Yilmaz, 2009).

It is known that elements and different solutions introduced to seeds have an impact on germination and seedling growth, especially, some macro or micro nutrition elements such as potassium or boron stimulates it. However, seed germination is lagged and detentioned concerning some toxic element concentrations like high percentages of iron or sulphur (Katkat and Kaçar, 2009).

Petrescu et al. (2014) observed that the cadmium decreased seed germination in Salvia officinalis, germination percentages were $81.00 \%$ (10 ppm), 59.66\% (50 ppm) and $21.33 \%$ (100 $\mathrm{ppm}$ ), compared to control $93.33 \%$. Contrary to that, our observations showed that increasing $\mathrm{CdCl}_{2}(2,6,10 \mathrm{ppm})$ and $\mathrm{PbCl}_{2}(50,100,500 \mathrm{ppm})$ concentrations had no significant effect on seed germination of $S$. candidissima subsp. occidentalis, but increasing concentrations of $\mathrm{CuCl}_{2}$ $(20,60,150 \mathrm{ppm})$ had a significant inhibitory effect on seed germination of $S$. candidissima subsp. occidentalis. We can say that $S$. candidissima subsp. occidentalis could tolerate effect of $\mathrm{CdCl}_{2}$ (up to $10 \mathrm{ppm}$ ) and $\mathrm{PbCl}_{2}$ (up to $500 \mathrm{ppm}$ ) during seed germination stage.

The observations about biomass showed that increasing $\mathrm{CdCl}_{2}(2,6,10 \mathrm{ppm})$ and $\mathrm{PbCl}_{2}(50$, $100,500 \mathrm{ppm}$ ) concentrations had no significant effect on biomass increase of $S$. candidissima subsp. occidentalis seedlings, but increasing concentrations of $\mathrm{CuCl}_{2}(20,60,150 \mathrm{ppm})$ had a significant inhibitory effect on biomass increase of $S$. candidissima subsp. occidentalis seedlings. We can claim that $S$. candidissima subsp. occidentalis could tolerate effect of $\mathrm{CdCl}_{2}$ (up to $10 \mathrm{ppm}$ ) and $\mathrm{PbCl}_{2}$ (up to $500 \mathrm{ppm}$ ) on biomass increase during seedling stage.

Petrescu et al. (2014) observed that cadmium solutions applied to S. officinalis seeds increased radicle development at concentrations of $10 \mathrm{ppm}$, but decreased at concentrations of $50 \mathrm{ppm}$ and $100 \mathrm{ppm}$. Although our findings about seedling growth showed that increasing $\mathrm{CdCl}_{2}(2,6,10 \mathrm{ppm})$ concentrations had no distinct impact on plant development of $S$. candidissima subsp. occidentalis seedlings, but increasing concentrations of $\mathrm{PbCl}_{2}(50,100$, $500 \mathrm{ppm})$ and $\mathrm{CuCl}_{2}(20,60,150 \mathrm{ppm})$ had significant inhibitory effects on seedling growth of $S$. candidissima subsp. occidentalis seedlings. There is an interesting result about effect of $\mathrm{CdCl}_{2}$ concentrations on root growth. Different $\mathrm{CdCl}_{2}$ concentrations had significant inhibitory effect on root growth of $S$. candidissima subsp. occidentalis seedlings.

Bini et al. (2012) reported that Taraxacum officinale is a bioindicator plant and also has ethnobotanical usage for liver disease and cooking, but its heavy metal accumulation ability is harmful for human health. $S$. candidissima subsp. occidentalis is also tolerant to both cadmium and lead (at a certain level) and is consumed as herbal tea by the local people, according to the information transmitted orally during field studies. therefore we can assert negative effects with T. officinale is valid for S. candidissima subsp. occidentalis. However, Carman Sosa et al. (2016) revealed that Tagetes minuta plants growing in areas polluted with lead, while lead was not found in essential oil and some ingredients were generated more than control group. 
Novo et al. (2013) reported concerning the capacity of Salvia verbenaca to bear trace metals and actively replied to the following oxidative stress. S. candidissima subsp. occidentalis Hedge is also like $S$. verbanaca in terms of tolerance to heavy metal stress.

Chand et al. (2016) stated that when the essential oil is extruded through hydrodistillation, the heavy metals in the plant do not migrate to the essential oil, so the Pelargonium graveolens plant is suitable for the volatile oil even if it is grown in places exposed to heavy metal pollution. S. candidissima subsp. occidentalis has also valuable volatile oil content, its tolerance to $\mathrm{Pb}$ and $\mathrm{Cd}$ makes this plant appropriate for grown in polluted areas for volatile oil production.

Similarly, to findings of this study, Torun (2019) observed that Salvia officinalis was showed no significant difference comparatively water ingredient and chlorophyll fluorescence under salt and cobalt stress, but relative growth rate was raised after salt + cobalt application and it can be said that the mixture of salt and cobalt is suitable for improving toleration of $S$. officinalis for stress (Torun, 2019). Heavy metals can stimulate plant growth performance at a certain level (Arif et al., 2016).

Duka et al. (2015) stated that Salvia officinalis plant should be checked for heavy metal ingredients before being processed for human consumption. Similar to the findings of Duka et al. (2015), we can say that it is necessary to be careful in consuming Salvia candidissima subsp. occidentalis as it is tolerant to heavy metals such as cadmium and lead, if the gathering areas of the plant in question are exposed to cadmium and lead pollution, we can say that the plant can be harmful to people consuming it due to heavy metal accumulation.

\section{CONCLUSION}

S. candidissima subsp. occidentalis is a perennial plant that can be used in park and garden landscaping because of its white and interesting flowers. In addition, it can be grown for medical purposes owing to its chemical substances such as diterpenoids. According to the results, it can be said that $S$. candidissima subsp. occidentalis can be grown in habitats contaminated with both cadmium and lead due to its tolerance ability against heavy metals. It has been revealed that ecophysiological parameters such as\% Germination, Hypocotyl and radicle lengths, biomass, SVI and MTI are the values that must be taken into consideration when examining the effects of heavy metals on the plant species in question.

\section{Declaration of Conflicting Interests and Ethics}

The author declare no conflict of interest. This research study complies with research and publishing ethics. The scientific and legal responsibility for manuscripts published in IJSM belongs to the author.

\section{Orcid}

Gulcin Isik (D) https://orcid.org/0000-0001-5502-1026

\section{REFERENCES}

Angelova, V.R., Ivanova, R.I., Todorov, J.M., Ivanov, K.I. (2017). Potential of Rapeseed (Brassica napus L.) for Phytoremediation of Soils Contaminated with Heavy Metals. J. of Env. Prot. and Ecol., 18(2), 468-478.

Arif, N., Yadav, V., Singh, S., Singh, S., Ahmad, P., Mishra, R.K., Sharma, S., Tripathi, D.K., Dubey, N.K., Chauhan, D.K. (2016). Influence of High and Low Levels of Plant-Beneficial Heavy Metal Ions on Plant Growth and Development. Front. in Env. Sci., 4, Article no: 69, 1-11. https://doi.org/10.3389/fenvs.2016.00069

Bini, C., Wahsha, M., Fontana, S., Maleci, L. (2012). Effects of Heavy Metals on Morphological Characteristics of Taraxacum officinale Growing on Mine Soils in NE Italy. J. of Geochem. Expl., 123, 101-108. https://doi.org/10.1016/j.gexplo.2012.07.009 
Carman Sosa, M., Salazar, M.J., Zygadlo, J.A., Wannaz, E.D. (2016). Effects of Pb in Tagetes minuta L. (Asteraceae) Leaves and Its Relationship with Volatile Compounds. Ind. Crops and Prod., 82, 37-43. https://doi.org/10.1016/j.indcrop.2015.12.011

Chand, S., Singh, G., Patra, R.D.D. (2016). Performance of Rose Scented Geranium (Pelargonium graveolens) in Heavy Metal Polluted Soil vis-a-vis Phyto-Accumulation of Metals. Int. J. of Phy., 18(8), 754-760. https://doi.org/10.1080/15226514.2015.1131236

Davis, P.H. (1985). Flora of Turkey and the East Aegean Islands, Salvia L., I. C. Hedge, Suppl.: 7, p. 400-461 - Edinburgh Univ. Press.

Duka, I., Shallari, S., Maçi, A., Rada, Z., Shehu, J. (2015). Heavy Metals Accumulation by Aromatic Plant Salvia officinalis Irrigated with Treated Wastewater. Agro-Env. \& Ecol., Anglisticum J (IJLLIS), 4(10), 86-92. http://dx.doi.org/10.0001/(aj).v4i10.1185

Gangwar, S., Singh, V.P., Tripathi, D.K., Chauhan, D.K., Prasad, S.M., Maurya, J.N. (2014). Plant Responses to Metal Stress: The Emerging Role of Plant Growth Hormones in Toxicity Alleviation. Em. Tech. and Man. of Crop Stress Tol., 2, 215-248. https://doi.org/10.1016/B978-0-12-800875-1.00010-7

Gill, T., Dogra, V., Kumar, S., Ahuja, P.S., Sreenivasulu, Y. (2012). Protein Dynamics During Seed Germination Under Copper Stress in Arabidopsis Over-Expressing Potentilla Superoxide Dismutase. J. of Pl. Res., 125(1), 165-172. https://doi.org/10.1007/s10265-011$\underline{0421-2}$

He, J.Y., Ren, Y.F., Zhu, C., Jiang, D.A. (2008). Effects of Cadmium Stress on Seed Germination, Seedling Growth and Seed Amylase Activities in Rice (Oryza sativa). Rice Sci., 15(4), 319-325. https://doi.org/10.1016/S1672-6308(09)60010-X

Katkat, V., Kaçar, B. (2009). Bitki Besleme (Plant Nutrition), Nobel Yayın Dağıtım, Ankara.

Murthy, S.M., Tejavathi, D.H. (2016). Effect of Osmopriming on Seed Germination and Seedling Vigour in Macrotyloma uniflorum (Lam.) Verd C. Int. J. of Pl., Ani. and Env. Sci., 6(2), 71-77.

Novo, L.A.V., Covelo, E.F., González, L. (2013). The Potential of Salvia verbenaca for Phytoremediation of Copper Mine Tailings Amended with Technosol and Compost. Water Air Soil Pollut., 224, 1513-1522. https://doi.org/10.1007/s11270-013-1513-5

Petrescu, I., Dobosan, I., Madosa, E., Gorinoiu, G., Bala, M., Banu, C., Becherescu, A., Dragunescu, A., Sirbu, C. (2014). Effect of Cadmium on Seed Germination and Seedling Development at Salvia officinalis L. Abstracts Book of J. of Biotech., 115.

Scheuhammer, A.M., Beyer, W.N., Schmitt, C.J. (2008). Lead, Encyclopedia of Ecology, Elsevier.

Sen-Utsukarci, B., Gurdal, B., Bilgin, M., Satana, D., Demirci, B., Tan, N., Mat, A. (2019). Biological Activities of Various Extracts from Salvia cassia Sam. ex Rech.f. and Chemical Composition of Its Most Active Extract. Rec. Nat. Prod., 13(1), 24-36. http://doi.org/10.25135/rnp.68.18.02.090

Singh, A., Prasad, S.M. (2011). Reduction of Heavy Metal Load in Food Chain: Technology Assessment. Rev. Environ. Sci. Biotech., 10, 199-214. https://doi.org/10.1007/s11157-011$\underline{9241-\mathrm{Z}}$

Topcu, G., Tan, N., Ulubelen, A., Sun, D., Watson, W.H. (1995). Terpenoids and Flavonoids from the Aerial Parts of Salvia candidissima. Phytochem., 40 (2), 501-504. https://doi.org/10.1016/0031-9422(95)00245-3

Torun, H. (2019). Cobalt+Salt-Stressed Salvia officinalis: ROS Scavenging Capacity and Antioxidant Potency. Int. J. of Sec. Met., 6(1), 49-61. https://doi.org/10.21448/ijsm.484954

Turner, R.G., Marshall, C. (1972). The Accumulation of Zinc by Subcellular Fractions of Roots of Agrostis tenuis Sibth. In Relation to Zinc Tolerance. The New Phytol., 71(4), 671-676. https://doi.org/10.1111/j.1469-8137.1972.tb01277.x 
Ulubelen, A., Tan, N., Topcu, G. (1997). Terpenoids from Salvia candidissima subsp. candidissima. Phytochem., 45(6), 1221-1223. https://doi.org/10.1016/S0031-9422(97)0014 $\underline{6-5}$

Ulubelen, A., Topcu, G. (1998). Chemical and Biological Investigations of Salvia Species Growing in Turkey. Stu. in Nat. Pro. Chem., 20, 659-718. https://doi.org/10.1016/S1572$\underline{\text { 5995(97)80040-3 }}$

Ulubelen, A., Topcu, G., Tan, N. (1992). Diterpenoids from Salvia candidissima. Tetrahedron Lett., 33 (47), 7241-7244. https://doi.org/10.1016/S0040-4039(00)60883-3

Ulubelen, A., Topcu, G., Tan, N. (1992). Rearranged Abietane Diterpenes From Salvia candidissima. Phytochem., 31(10), 3637-3638. https://doi.org/10.1016/0031-9422(92)8374 $5-\mathrm{K}$

Yucel, E. (2000). Effects of Different Salt, Nitrate and Acid Concentrations on the Germination of Some Salvia Species Seeds. Seeds Sci. \& Tech., 28, 853-860.

Yucel, E., Yilmaz, G. (2009). Effects of Different Alkaline Metal Salts (NaCl, $\left.\mathrm{KNO}_{3}\right)$, Acid Concentrations $\left(\mathrm{H}_{2} \mathrm{SO}_{4}\right)$ and Growth Regulator $\left(\mathrm{GA}_{3}\right)$ on the Germination of Salvia cyanescens Boiss. \& Bal. Seeds. Gazi Uni. J. of Sci., 22 (3), 123-127. 